\title{
Neoclassical versus Neoricardian Schools on Wage Determination
}

\author{
FAZIL KAYIKÇI \\ Yıldız Technical University Department of Economics \\ Email: fkayikci@yildiz.edu.tr \\ Tel: +902123836818
}

\begin{abstract}
In this paper, theories of the Neoclassical School and the Neoricardian schools were stated and compared about the wage determination and distribution: the Marginal Productivity Theory and the Sraffa System. The Neoclassical theory was examined firstly; its evolution, main characteristics and what results we will face with when we relax its central assumptions. Then, the Neoricardian theory was examined; its relations with Ricardo and Marx, its critiques about the marginal productivity theory and the themes of the system. The main difference between Sraffa and Neoclassics was found as the marginal productivity theory uses the marginal products and prices as data in order to determine the wages and profits, but in the Sraffa system, with the help of the physical conditions of production, one of the unknown from the profit rate, wage and prices is sufficient to determine all of the others simultaneously. In addition, in the Sraffa system, a commodity can be both a factor of production and output whereas in the marginal productivity theory production process has only one way direction.
\end{abstract}

Keywords: Marginal Productivity Theory, Sraffa, Wage Distribution, Neocalassical School, Neoricardian School.

\section{Introduction}

Economic theories differ since they focus on different aspects of economy and interpret them in different ways. Besides, the methodology they use and the assumptions they accept are the other reasons for the presence of different economic theories or different schools of economic thought. According to Wolf and Resnick, "There are some basic properties for all theories; these may be the ability to select objects to theorize about, to define those objects or to establish logical linkages among the objects" (Wollf and Resnick, 1987, 13). These properties provide a basis for analyzing different aspects of theories or for distinguishing alternative theories. Theories define and link their respective objects to produce their alternative understanding of the economy.

Since economics is a social science, there is no clear and definite method with which we can compare the theories of different schools and choose one of them as the best. Sociological, political, cultural and ideological factors also influence us when we study and compare the theories as they influence the theorists. Because of these factors, the Neoclassical School for example, is seen as a mainstream economic thought. The utilization of mathematical tools and easy to teach characteristic of this school can be other reasons for this. However, according to Mair and Miller (1991, 4), "The subject of economics is so broad and complex that any one of the schools cannot explain everything perfectly. Thus, many of the schools try to specialize in different matters. As a result, they should be seen as a complementary rather than rival". Some of the schools may have a better explanation on production functions, some of which are about exchange relationships, banking and investment analysis, monetary systems, firm theory, etc. In this paper, theories of the Neoclassical School and the NeoRicardian schools are stated and compared about the wage 
determination and distribution: the Marginal Productivity Theory and the Sraffa System. However, before the analysis of their specific theories about the subject, it will be beneficial to state briefly their ideas, methodologies, assumptions and conclusions about the economy in general.

After stating the characteristics and methodologies of these economic theories, reasons for presence of different schools of economic thought and briefly presenting the general features, assumptions, world views, methodologies, logics and conclusions of the Neoclassical and the NeoRicardian approaches, we are going to analyze the subject of wage determination and distribution in these schools. We will examine the Neoclassics firstly (The Marginal Productivity Theory); its evolution, main characteristics and what results we will face with when we relax its central assumptions. Then, we will examine the NeoRicardians (The Sraffa System); its relations with Ricardo and Marx, its critiques about the marginal productivity theory and the themes of the system. Finally, we will derive some conclusions about our subject by comparing the two systems.

\section{The Neoclassical School}

Walras' general equilibrium theory, Edgeworth's findings about exchange relationships, Pareto's optimality condition and Clark, Wicksell, Wicksteed and others' emphasis on marginal concept are the main features for the foundation of the Neoclassical School. Neoclassic theory gives importance to individuals and their acts such as consuming, producing and exchanging to maximize their utility. Its assumption about human nature is that people are rational utility maximizers. Consumption, production and all other actions are the results of individuals' decisions and price mechanism coordinates these decisions. According to Neoclassics, society consists of individuals and in order to increase social welfare we should increase the welfare of individuals.

Neoclassics are not interested in social classes or the ownership of the production functions, they believe in market mechanism and especially the supply and demand concepts from which prices are derived. All actions in market mechanism are thought to be free and voluntary and every transaction or exchange relationship is thought to be beneficial to all parties since it would not occur otherwise. From this, Neoclassics arrive at the concepts such as efficiency, marginal benefit and optimal use of the scarce resources among the alternative choices, which are the basis of the Neoclassic School.

\section{The Neoricardian School}

The NeoRicardian School (sometimes called as Sraffian School, Cambridge school or Italian school) is represented by the growth theories of Robinson, Kaldor and Pasinetti, price and distribution theory of Sraffa, Dmitriev and Bortkiewicz. The school is generally evaluated in its relation with Marx's value theory or Neoclassical distribution theory. However, "Much of their work takes the form of a more or less conscious return to the method of Ricardo" (Rowthorn, 1974, p.71). According to Dobb (1973, p.261);

What is particularly striking about the Sraffa system is its rehabilitation of the Ricardo-Marx approach to problems of distribution from the production side, so that relative prices are independent of the pattern of consumption and demand.

The main characteristic of the economists of the school is their rejection of subjective individualism and of the supply and demand's roles in determination of income distribution. They also include the reality of social classes in their analysis. They also ignore the uncertainty and expectations; they use the general equilibrium model, perfect competition and the division of classes in society as assumptions. Their aim is to show that the Ricardian classical political economy can be used as a basis for a reconstruction of modern economic theory. 


\section{Theory of Wages and Distribution in Neoclassical School}

The classical theory of value depended on the principle that the prices of produced goods tend to converge to their long run cost of production. Classical economists defined the cost of production as the sum of the money value of product's inputs. And since they took physical factor requirements as given, their theorem's validity depended on their ability to determine the input or factor prices. They gave some explanations for the determination of different types of factors' prices but they felt difficulties in explaining the wages because labor has a special characteristic and were different from other inputs. Thus, they attempted to embed labor into the produced goods.

Classical economists used the Malthusian theory of population and created a subsistence wage theory. It is a theory that the wage rate is just enough to enable the worker to reproduce himself/herself from one work day to the next, it is just enough for reproduction of labor power. David Ricardo and others used the Malthusian population theory to argue that wages above subsistence level induce increase in the population since it increases the welfare of the workers, thus, an increase in population means an increase in labor supply; this increase in labor supply pushes down the wage rates and leads to a long run equilibrium in which wage provides workers a standard of living that is just equal to subsistence level. However, this approach created some problems; for example, Kazgan (1980) argued that it was seen from the empirical data that increase in wage levels did not result in increase in population growth; on the contrary, population growth declined as the standards of living improved. Even if we assume that this empirical result does not hold, there need to be very long time period for the population being responded to the change in the welfare level and thus for the market wage being responded to the change in the subsistence level wage. Hence, the subsistence wage theory lost its relevance.

As we saw their attempts to embed labor into capital above, in classical view, beside the physical machinery, capital also consists of wealth that is spent for the purchase of any other factor of production. In the labor case, the advances made to workers were treated as part of capital and were known as the wage fund. In the sense of more clear definition; since production process requires time, at the end of every production period we need to give some part of the product to the workers to make them meet their basic needs and sustain themselves during the production period, this part is called the wage fund. We can state this as

$$
w L=P C
$$

where $\mathrm{w}$ is the money wage for workers, $\mathrm{L}$ is the number of workers hired, $\mathrm{P}$ is the price vector of goods and $\mathrm{C}$ is the vector of goods that is consumed by workers. We can see from this statement that if the wage fund is fixed, the wages and employment levels will be inversely related.

The wage fund theory, which is attributed to John Stuart Mill, is not only important for reflecting the classical view about the wage determination but it is also important for the explanation of the profit and of the capital's roles as being a productive factor and being the source of wage payment mechanism in the production process. "From the point of view of the history of economic thought this system is important for the role it played in the transition from the classical to the neoclassical approach." (Screpanti and Zamagni, 1993, p.101). Nevertheless, the wage fund theory met a number of critiques which emphasize that, for example, employment does not involve advancing consumption goods to tide workers over during the course of production; instead, the decision to hire factors should be seen as a function of the profitability and hence the productivity of the factors employed. Then, many economists tried to explain factor pricing from the profitability perspective. One of them was Francis Walker, who was heavily influenced by Stanley Jevons, argued that employment decisions are driven by calculations of the profitability of labor, therefore; given the price of output, wages are linked to the productivity of labor. Wages are the residual share of output after profits, interest and rent are deducted. Hence, if shares other than labor are fixed, an increase in productivity will lead to an increase in wages (Mandler, 1999). 
Walker's theory that the productivity of labor is the primary determinant of the wages gained wide currency. Given the popularity of calculus and explicit models of maximization, marginal productivity was then a mathematically natural step. Henry George combined Walker's view of linking wages to productivity with classical rent theory to conclude that wages were equal to the product of labor on marginal land. Then, George's theory pro- vided the direct inspiration for Clark's marginal productivity theory. (Mandler, 1999, p.64).

The marginal productivity theory tells that each factor of production or input is paid according to its marginal productivity which can be calculated adding or withdrawing one unit of that factor and measuring the change in the total product as a response to change in that input while the quantity of other factors are being constant. If the amount of one factor is held constant and other factor is increased (assuming there are only two factors), then the latter's marginal product will increase at a decreasing rate. For example, if we set the number of capital, say machine, constant and increase the number of workers, workers' marginal productivity will increase but not so much at higher levels of employment since workers cannot easily find a machine to work with. Thus, profit maximizer firm does not hire infinite amount of labor; it hires up to the point that the value of the marginal product of labor equals to its price, wage. Wages cannot be below the value of the marginal product of labor; if it can, the firm will hire more labor since this action increases the profit. Thus, wages will start to increase since the demand for labor increases. The wages cannot be above the value of the marginal product of labor for the same reason; firm does not hire workers since it makes loss by hiring at that wage level and wages will decrease as a response to decrease in demand. Thus, labor will be rewarded according to its marginal productivity.

We can see the situation from a simple example where there are two factors, capital and labor: $Q=F(K, L)$. We state the profit function of the firm and find the prices of the factors in order to achieve maximum profit;

$$
\begin{aligned}
& \Pi=P \cdot Q-(r K+w L) \\
& \frac{\partial \Pi}{\partial K}=\frac{\partial Q}{\partial K} \cdot P-r=0 \rightarrow r=\frac{\partial Q}{\partial K} . P \\
& \frac{\partial \Pi}{\partial L}=\frac{\partial Q}{\partial L} \cdot P-w=0 \rightarrow w=\frac{\partial Q}{\partial L} \cdot P
\end{aligned}
$$

(Wage is equal to the value of the marginal product of labor)

To look at the issue from another perspective, let's consider the profit maximizer firm's decision for factor demand. Ferguson (Ferguson, 1969), states that if the production function is like

$$
Q=F\left(x_{1}, x_{2}, \ldots, x_{n}\right)
$$

Then total cost is $\min \sum_{p_{i} x_{i}}$ subject to $Q=F\left(x_{1}, x_{2}, \ldots ., x_{n}\right)$

Then we derive the Lagrange function as

$$
L=\sum p_{i} x_{i}-\lambda\left[F\left(x_{1}, x_{2}, \ldots ., x_{n}\right)-Q\right]
$$

Setting the first order conditions for minimization of costs (maximization of profits) 


$$
\begin{aligned}
& \frac{\partial L}{\partial x_{i}}=p_{i}-\lambda \frac{\partial Q}{\partial x_{i}}=0 \quad \text { for } \mathrm{i}=1 \\
& \frac{\partial L}{\partial \lambda}=\left[F\left(x_{1}, x_{2}, \ldots, x_{n}\right)-Q\right]=0
\end{aligned}
$$

We reach to conclusion that

$$
\frac{\frac{\partial Q}{\partial x_{i}}}{p_{i}}=\frac{\frac{\partial Q}{\partial x_{j}}}{p_{j}} \quad \text { for } \mathrm{i}, \mathrm{j}=1,2, . ., \mathrm{n}
$$

That is; if a production function is $F(x, y, z, \ldots)$, we should have

$$
\frac{\text { marg.product of } x}{\text { price of } x}=\frac{\text { marg.product of } \mathrm{y}}{\text { price of } \mathrm{y}}=\frac{\text { marg.product of } z}{\text { price of } \mathrm{z}}=\ldots . .=\frac{1}{\text { marg.cost }}
$$

Competitive firm maximizes profits by equating marginal cost to the price of the output. The profit maximization implies cost minimization and this means paying to factors according to their marginal productivity. If a firm maximizes profit, then; marginal cost will be equal to the price of the product. Hence;

$$
\frac{\text { marginal product of labor }}{\text { wage }}=\frac{1}{\text { price of product }} \rightarrow w=m p l \times p
$$

(the wage will be equal to marginal value product of labor).

Clark (1924), one of the founders of the marginal productivity theory, attributes a position to the theory as being a just distribution which provides normative principles. He claims that the problem of relative shares of land, labor and capital in the classical distribution theory, disappears in the marginal productivity theory; the various categories of income are described as rewards for various kinds of sacrifice, each of which provides a necessary contribution to production: the capitalist forgoes the consumption of his capital by receiving interest (or profit) as his reward, the landlord forgoes the use of his land by receiving rent as his reward and the worker forgoes his leisure by receiving wage as his reward. By describing the situation in this way, he presents the relationship among the capitalist, the landlord and the worker as an essentially harmonious one in which each of them makes his/her different contribution to production and receives his/her appropriate reward.

The theory and its assumptions also guarantee the total exhaustion of product among the factors; if the production function is linear and homogeneous of degree one (or has constant returns to scale property), when factors get their marginal products, the total factor income will be equal to the total value of the product by the Euler Theorem, which is a special feature of this type of functions. According to Blaug (1997, p.421), "The hypothesis of total product is exhausted when each factor is rewarded by its marginal product was tried to be proved by many economists and A. W. Flux presented the suitable one." If the production function is $\mathrm{Q}=\mathrm{F}(\mathrm{x}, \mathrm{y}, \mathrm{z})$ then by the assumption of constant returns to scale;

$$
\frac{d Q}{Q}=\frac{d x}{x}=\frac{d y}{y}=\frac{d z}{z}=\text { constant }
$$


By the theorem of ratios, if $k=\frac{a}{b}=\frac{c}{d}=\frac{e}{f}$ then $k=\frac{p a+q c+r e}{p b+q d+r f}$ applying this theorem to above production function by multiplying each ratio with the first partial derivative of $\mathrm{Q}$, we have

$$
\frac{d Q}{Q}=\frac{\frac{\partial Q}{\partial x} \cdot x+\frac{\partial Q}{\partial y} \cdot y+\frac{\partial Q}{\partial z} \cdot z}{\frac{\partial Q}{\partial x} \cdot x+\frac{\partial Q}{\partial y} \cdot y+\frac{\partial Q}{\partial z} \cdot z}=\frac{d Q}{\frac{\partial Q}{\partial x} \cdot x+\frac{\partial Q}{\partial y} \cdot y+\frac{\partial Q}{\partial z} \cdot z}
$$

therefore;

$$
\frac{\partial Q}{\partial x} \cdot x+\frac{\partial Q}{\partial y} \cdot y+\frac{\partial Q}{\partial z} \cdot z=Q
$$

Hence; the total product is exhausted by factor payments since first partial derivatives of $\mathrm{Q}$ are the marginal products of $\mathrm{x}, \mathrm{y}$, and $\mathrm{z}$. Now, we can see this by the help of the Euler Theorem and with the Cobb-Douglass production function as an example:

The Euler theorem states that if $\mathrm{F}(\mathrm{x}, \mathrm{y}, \mathrm{z})$ is a homogeneous function of the $\gamma$ degree, it has the property that

$$
\frac{\partial Q}{\partial x} \cdot x+\frac{\partial Q}{\partial y} \cdot y+\frac{\partial Q}{\partial z} \cdot z=\gamma Q
$$

or, if $\mathrm{F}(\mathrm{x}, \mathrm{y}, \mathrm{z})$ is a homogeneous function then $\mathrm{F}(\mathrm{kx}, \mathrm{ky}, \mathrm{kz})=\mathrm{k} \gamma \mathrm{F}$ where $\mathrm{k}$ is an arbitrary positive constant and $\gamma$ is the degree of the function. The value of $\gamma$ determines the returns to scale that obtain for a particular homogeneous production function. For example when $\gamma$ is higher than one, if we double all the inputs, output will more than double and we have increasing returns to scale. To illustrate this, let's see the CobbDouglass production function as an example;

$\mathrm{Q}=\mathrm{AL}^{\alpha} \mathrm{K}^{\beta}$ where $\mathrm{A}$ is a technological parameter. Then, the marginal product of labor is

$$
\frac{\partial Q}{\partial L}=\alpha A L^{\alpha-1} K^{\beta}=\alpha \frac{Q}{L}
$$

And similarly the marginal product of capital is

$$
\frac{\partial Q}{\partial K}=\alpha A L^{\alpha} K^{\beta-1}=\beta \frac{Q}{K}
$$

By the Euler Theorem we know that;

$$
\frac{d Q}{L} \cdot L+\frac{d Q}{K} \cdot K=\gamma Q
$$

and substituting the above results of Cobb-Douglass function into Euler Theorem; 


$$
L \alpha\left(\frac{Q}{L}\right)+K \beta\left(\frac{Q}{K}\right)=\gamma Q \rightarrow \alpha+\beta=\gamma
$$

if the sum of alfa and beta is equal to one, $\mathrm{Q}$ is necessarily first degree homogeneous function. (Blaug, 1997).

Bohm Baverk has directed the following objection to the marginal productivity theory; if the product of the marginal unit of labor equals to the wage rate and the marginal product of labor has the diminishing returns property, the workers other than the marginals will receive less than the amount that they add to the total product; labor therefore will fail to receive its intramarginal surplus, thus the marginal productivity theory leads to the exploitation of labor. Clark replied to this objection by telling that

The theory assumes each factor as homogeneous, all units of the factor are equally efficient; the marginal productivity of labor falls as more labor is added to a given amount of capital because capital per unit of labor is falling" (Blaug, 1997, p.409).

We can conclude that the greater marginal productivity of fewer workers is only the result of the fact that they have more capital to work with; the greater productivity of fewer workers may be attributed to the productivity of capital. However, it may result that there is no such thing as a specific marginal product of a factor: factors of production are complementary, and the marginal product of one factor is a consequence of the marginal product of other factors.

Hobson also criticized the theory from the above perspective of Clark by raising the question that "How variations in output can be attributed to the labor alone?" (Blaug, 1997, p.417). Marshall, by replying Hobson, in fact introduced the concept of the marginal net product of a factor, which measures the marginal product of joint additions of labor and capital and subtracts the cost of one factor to determine the net product of the other. According to Marshall, It can be assumed that capital is completely adaptable in form, so that labor's product can be separated from the joint product of the combined factors. But in the short run, firms are limited in their ability to substitute factors for one another and most short run calculations involve cost other than purely wages. Thus, a marginal net product concept is necessary when investigating the short run marginal adjustments made by firms. (Cartter, 1959, pp.24-25).

The marginal productivity theory claims that, if the workers are paid above their marginal product, it will result in an excess supply of labor, which causes unemployment. This unemployment can be eliminated by reducing the wages. However, Keynes argues that wages are incomes as well as costs and reducing wages will reduce the income and hence the demand for products as well, which reduces the demand for labor and causes unemployment again (Keynes, 1964).

\section{Theory of Wages and Distribution in Neoricardian School}

Piero Sraffa, an Italian economist, criticized the theories that consider only supply and demand. He analyzed the works of classic economists, especially David Ricardo and he used the criticisms of Joan Robinson about Marx and other theorists to set up his own model and to provide a response for a new distribution theory by publishing the book, "Production of Commodities by Means of Commodities: A Prelude to a Critique of an Economic Theory". The aim of the book, in fact, was a prelude to a critique of an economic theory as it appears in the title of the book, but then it also aimed at being the basis for a critique of the marginal theory of value and distribution. This book is considered as the birth of the NeoRicardian School, not only criticized the marginal productivity theory but also established a new distribution theory. According to Sraffa the marginal approach requires attention to be focused on change as there can be neither marginal product nor marginal cost without change either in the scale of an industry or in the proportions of factors of production since the marginal productivity theory measures the change in 
the amount of output as a response to change in the amount of factors of production. The conditions of production (social and technical) and the real wage paid to workers specified in terms of physical quantities of commodities are sufficient to determine the rate of profit and all prices of production. In the Sraffa system, the distribution of income among the classes is not the end of the process of determination of prices; rather, prices are derived from distribution conditions. Social relations are embedded into the model in addition to the market relations; wages and profit are determined from the social classes' war.

The properties emerging from the class relations within which production process are carried out; the social properties of production activity do not make the economic system described by Sraffa, a general system of competitive relationships among individuals, but they form a system of social relations whose central problem is the division of the surplus between capitalists and workers. (Screpanti and Zamagni, 1993, p.5). As a result, Sraffa appreciates the views of classic economists with a new theory and method. According to Meek (1973, p.161),

Sraffa's system could be alternatively regarded simply as an unorthodox theoretical model designed to solve the traditional problem of value in a new way, as an implicit attack on modern marginal analyses or as a sort of magnificent rehabilitation of the classical (and up to a Marxian) approach to certain crucial problems relating to value and distribution.

Sraffa explains the assumptions and simplicities of his system in the preface of his book as, "No changes in output and no changes in the proportions in which different means of production are used by an industry are considered, so that no question arises as to the variation or constancy of returns" (Sraffa, 1960, preface). Sraffa's equational system provides a series of products that can be both outputs and inputs. There are $\mathrm{k}$ equations for k products, all of them appear both as inputs for some or all other products and as outputs. At the left hand side of the equational system, inputs are multiplied by their prices and summed, then, that sum is multiplied by the profit rate and is equated to the right hand side where the outputs times their prices takes place (Kayal1, 1978):

$$
\begin{aligned}
& \left(\left(A_{a} \cdot p_{a}\right)+\left(B_{a} \cdot p_{b}\right)+\ldots \ldots .+\left(K_{a} \cdot p_{k}\right)\right) \cdot(1+r)=A p_{a} \\
& \left(\left(A_{b} \cdot p_{a}\right)+\left(B_{b} \cdot p_{b}\right)+\ldots \ldots .+\left(K_{b} \cdot p_{k}\right)\right) \cdot(1+r)=B p_{b} \\
& \text { - } \\
& \text { - } \\
& \left(\left(A_{k} \cdot p_{a}\right)+\left(B_{k} \cdot p_{b}\right)+\ldots \ldots .+\left(K_{k} \cdot p_{k}\right)\right) \cdot(1+r)=K p_{k}
\end{aligned}
$$

There are $\mathrm{k}$ equations in the system. Choosing one of the prices as numeraire makes the number of unknowns k-1 and when we add the profit rate which is unknown, there will be k unknown in the system. Thus, in his system, both prices and the rate of profits are simultaneously determined by the conditions of production of all the products that can be both inputs and outputs. Sraffa calls these products as basics and he emphasizes that it is only the conditions of production of basics that play a part in determining prices and the rate of profit. If there are products that they do not play a productive role as inputs (nonbasics and luxuries), then they play no role in the determination of the system. Then, he gives an example as a production system with a surplus as:

$$
\begin{aligned}
& \text { 12t.Iron }+280 \text { qr.W heat } \rightarrow \text { 575qr.Wheat } \\
& \text { 8t.Iron }+120 \text { qr.W heat } \rightarrow \text { 20t.Iron }
\end{aligned}
$$


The exchange ratio is $15 \mathrm{qr}$. of wheat for $1 \mathrm{t}$. of iron and the corresponding rates of profit in each industry is 25 percent. Sraffa also finds a standard commodity, which Ricardo looked for analyzing the effects of distribution share's changes on this standard commodity and could not find it. He defines a standard commodity as a set of commodities arranged in a proportion that the commodity composition of the aggregate means of production and that of the aggregate product are identical. He gives an example as follows:

$$
\begin{aligned}
& 90 t . I r o n+120 t . \text { Coal }+60 \text { qr.Wheat }+\frac{3 . \text { labor }}{16} \rightarrow 180 t . \text { Iron } \\
& 50 t . \text { Iron }+125 t . \text { Coal }+150 q r . \text { Wheat }+\frac{5 . \text { labor }}{16} \rightarrow 450 t . \text { Coal } \\
& \text { 40t.Iron }+40 t . \text { Coal }+200 q r . \text { Wheat }+\frac{8 . \text { labor }}{16} \rightarrow 480 q r . \text { Wheat }
\end{aligned}
$$

The proportion in which the three commodities are produced in the new system are equal to those in which they enter its aggregate means of production. The standard commodity sought for is accordingly made up in the proportions 1 t. of iron : 3/2 t. of coal : 2 qr. Wheat. (Sraffa, 1960, p.19-20).

Thus, in the standard system, the ratio of the net product to the means of production would remain the same whatever variations occurred in the division of the net product between wages and profits and whatever consequent price changes.

Sraffa, in later chapters, shows how each of the price equations can be replaced by a series of labor terms with their adjusted date. This is what he calls reduction to dated quantities of labor. The reduction equation for each commodity consists of a series of labor terms that are multiplied by the wage, then multiplied by the rate of profit for the period intervening between the date of the labor input in question and the emergence of the final product:

$$
\left(L_{a} \cdot w\right)+\left(\left(L_{a_{1}} \cdot w\right) \cdot(1+r)\right)+\ldots . .+\left(\left(L_{a_{n}} \cdot w\right) \cdot(1+r) n\right)+\ldots .=A \cdot p_{a}
$$

He then consider the extensions of his model as the cases in joint production, where he supposes two of the commodities can be jointly produced by a single industry or by a single process, or in the fixed capital, which can be considered as a special case for a joint production since the analyses of fixed capital requires that partially used up machines can be treated as joint products, or in the switching of techniques, where he supposes that for the production of one of the commodities two alternative methods are known and where the preference of this methods varies with the rate of profits.

\section{Conclusion}

Sraffa's aim was to criticize the Neoclassical approach, namely the marginal productivity theory, but at the same time, he established his own distribution theory. Thereafter, a debate started in the academic world about the distribution theories of these two approaches. After presenting the assumptions, techniques, beliefs and resulting propositions of the Neoclassical and Sraffian approaches about the wage determination and distribution in detail, in this section we will make comparisons, and reach some conclusions about their superiorities, weaknesses or their validities in economic theory and practice.

The marginal productivity theory can be criticized as not including the social concept such as social relations of individuals, their social status and class, which affect their decisions. It states itself away from the class concept and only interested in the maximization of something; moreover, it does not criticize the social results of the distribution process. In addition, according to Neoclassics, capital means a productive 
factor as any other one and earns its reward according to its marginal productivity so it does not matter to whom it belongs to. "The marginal productivity theory gives importance only the subjective structures of the individuals about the distribution of in- come. Thus, it isolates the relationships between the people, and it reduces the economic system to the technical relationships of the objects and psychological relationships of the individuals" (Akat, 1980, p.118). Akat, going one step further, mentions about the defense mechanisms of the marginal productivity theory for the possible critiques about not being social, and not providing the justice. In spite of the differences in the analyzing methods, all of the neoclassic value and distribution theories try to prove that the share of capitalists on the output is equal to their productive contribution to the product. Thus, they try to prove that the differences and inequalities of the income levels in capitalist system come from the differences in talents, saving propensities and similar technical reasons. Hence, they save the system from some possible reform suggestions (Akat, 1980). On the other hand, Sraffa embeds the social relations into his model by describing the wage determination process as including not only the technical conditions of production, but also social classes' competition to increase their share on output. Prices are derived from the social distribution conditions instead that distribution is derived from the price determination process.

Among the given conditions of the problem, or postulated data, a social datum is introduced from outside the market process. Thus, the boundaries of economics as a subject are drawn differently and more widely; they are drawn so as to include social and moreover institutional and historically relative, changing and changeable, conditions. (Dobb, 1973, p.261).

Sraffa uses social concept and classes' competition and physical conditions of production, but he is criticized as he did not include the demand and supply concepts. He does not mention about the demand and supply conditions enough, he considers generally the production conditions. "Since there are no unsold goods, there must be just sufficient demand to absorb net output with the prices and incomes ruling" (Robinson, 1980, p.286). However, Rowthorn (1974) thinks that, this inclusion or putting little emphasis on supply and demand are not important problems for the Sraffa system since Sraffa examines the economy that does not have variation, and his central aim is to investigate the social relations and production conditions. On the other hand, the marginal productivity theory neglects the supply side by defining only the motives for demanding factors and taking the supply as given.

Sraffa uses the concepts of wages, profit rates and prices, but he does not explain or define the market system in which these concepts are used. Since he emphasizes the physical production conditions and ignores the supply and demand conditions, his prices can be considered as prices of production rather than market prices. Moreover, it is not certain what the form of the market or the institutional setting is in the Sraffa system. On the other hand, the marginal productivity theory assumes perfect competition form of market, which is not an explanation of real market, but an approximation or idealization of the market system and loses its validity in the context of other type of market systems.

Sraffa criticizes the marginal productivity theory as being required a change in the amount of inputs and output. Sraffa is right in his criticism since we have to see a change (one unit change in only one input which makes change in output level) in order to determine the marginal products of the production factors. According to Sraffa, production process continuous to reproduce itself without any change. Divitçioğlu approves this as, "The marginal theory is a short run theory and it depends on little changes. It is far from bringing solutions to developing countries' problems since it requires little changes". (1977, p. 111). On the other hand, the Sraffa system is criticized as being a static rather than dynamic, since it does not require a change in input coefficients or production process. Hovewer, Robinson defenses Sraffa against these criticisms by comparing him to Neoclassics,

In the general equilibrium model, the story begins with an arbitrary stock of ready-made inputs which can be combined in various ways to produce a variety of different outputs. In the Sraffa system, the stock of 
inputs in existence today was the result of investments made in the past in order to produce today's output with the technique which is in use today. (Robinson, 1980, p.65).

Finally, the main difference between Sraffa and Neoclassics is that the marginal productivity theory uses the marginal products and prices as data in order to determine the wages and profits, but in the Sraffa system, with the help of the physical conditions of production, one of the unknown from the profit rate, wage and prices is sufficient to determine all of the others simultaneously. In addition, in the Sraffa system, a commodity can be both a factor of production and output whereas in the marginal productivity theory production process has only one way direction. Moreover, in the Sraffa system, not only prices of products depend on the prices of production factors but also prices of production factors depend on the prices of products.

\section{References}

Akat, A. S. (1980). İktisadi Analiz. Istanbul, Turkey: İ. Ü. İktisat Fakültesi Yayınları.

Blaug, M. (1997). Economic Theory in Retrospect. Cambridge, U.K.: Cambridge University Press.

Cartter, A. M. (1959). Theory of Wages and Employment. Germany: Homewood, Irwin.

Clark, J. M. (1924). The Socializing of Theoretical Economics. In R. G. Tugwell (Ed.) The Trend of Economics. New York, U.S.: Alfred Knopf.

Divitçioğlu, S. (1982). Üretim Değer ve Bölüşüm. Istanbul, Turkey: Ar Basin Yayin ve Dağitim.

Dmitriev, V. K. (1974). The Theory of Value of David Ricardo: An Attempt at a Rigorous Analysis. In V. K. Dmitriev (Ed.), Economic Essays on Value, Competition, and Utility. Cambridge, U.K.: Cambridge University Press.

Dobb, M. (1973). Theories of Value and Distribution since Adam Smith: Ideology and Economic Theory. Cambridge, U.K.: Cambridge University Press.

Ferguson, C. (1969). The Neoclassical Theory of Production and Distribution. Cambridge, U.K.: Cambridge University Press.

Kayalı, R. (1978). Neoklasik ve Neo-Rikardiyen Üretim ve Bölüşüm Teorilerinde Sermaye Sorunu. Istanbul, Turkey: Boğaziçi Üniversitesi Yayınları.

Kazgan, G. (1980). İktisadi Düşünce veya Politik İktisadın Evrimi. Istanbul, Turkey: Remzi Kitabevi.

Keynes, M. J. (1964). The General Theory of Employment, Interest and Money. New York, U.S.: Harcourt Brace and Company.

Mair, D., and Miller, A. (1991). A Modern guide to economic thought: an introduction to comparative schools of thought in economics. Cheltenham, U.K.: Edward Elgar Publishing.

Mandler, M. (1999). Dilemmas in Economic Theory: Persisting Foundational Problems of Microeconomics. Oxford, U.K.: Oxford University Press.

Marshall, A. (1961). The Principles of Economics. London, U.K.: Macmillan.

Meek, R. L. (1973). Studies in the Labor Theory of Value. London, U.K.: Lawrence \& Wishart.

Robinson, J. (1964). Economic Philosophy. London, U.K.: Penguin Books.

Robinson, J. (1980). Further Contributions to Modern Economics. Oxford, U.K.: Blackwell Publishing.

Rowthorn, B. (1974). Neo-Ricardianism or Marxism. New Left Review, 86: 63-87.

Screpanti, E., and Zamagni, S. (1993). An Outline of the History of Economic Thought. Oxford, U.K.: Clarendon Press.

Sraffa, P. (1960). Production of Commodities by Means of Commodities. Cambridge, U.K.: Cambridge University Press.

Wolff, R., and Resnick, S. A. (1987). Economics: Marxian versus Neoclassical Bargain Price. Maryland, U.S.: The Johns Hopkins University Press. 